\title{
Perbandingan Oral Care Menggunakan Povidone Iodine 1\% dengan Chlorhexidine 0.2\% terhadap Jumlah Bakteri di Mulut pada Pasien Penurunan Kesadaran
}

\author{
Ni Luh Widani ${ }^{1}$, Yusron Nasution ${ }^{2}$ \\ ${ }^{1}$ Sekolah Tinggi Ilmu Kesehatan, Sint Carolus Jakarta, ${ }^{2}$ Fakultas Kesehatan Masyarakat, Universitas \\ Indonesia \\ Email:widani24@gmail.com
}

\begin{abstract}
Abstrak
Oral care klien penurunan tingkat kesadaran tidak boleh diabaikan dan membutuhkan antiseptik oral yang mempunyai sifat antibakteri. Penelitian ini adalah penelitian kuantitatif dengan desain quasi eksperimen dengan kelompok kontrol, pre dan post test untuk mengidentifikasi perbandingkan povidone iodine $1 \%$ dengan chlorhexidine $0.2 \%$ terhadap jumlah koloni bakteri di mulut klien penurunan kesadaran. Hasil penelitian pada 30 responden yang diambil secara consecutive sampling dibagi tiga kelompok. Ada perbedaan yang signifikan penurunan jumlah koloni bakteri sebelum dan setelah oral care pada povidone iodine $(\mathrm{p}=0.007)$, chlorhexidine $(\mathrm{p}=0.001)$ dan air $(p=0.001)$. Perbandingan selisih jumlah bakteri antara povidone iodine $1 \%$, chlorhexidine $0.2 \%$ dan kontrol tidak signifikan $(\mathrm{p}=0,343)$. Disimpulkan chlorhexidine $0.2 \%$, povidone iodine $1 \%$ dan air minum masing-masing mempunyai kemampuan yang signifikan menurunkan koloni bakteri dan dapat digunakan sebagai pembilas oral care. Disarankan secara ekonomis air minum digunakan dalam oral care apabila klien penurunan kesadaran tidak mengalami infeksi mulut, dan chlorhexidine $0.2 \%$ atau povidone iodine $1 \%$ digunakan bila ada infeksi mulut.
\end{abstract}

Kata kunci: Chlorhexidine $0.2 \%$, koloni bakteri mulut, oral care, penurunan kesadaran, povidone iodine $1 \%$.

\section{The Comparison of Oral Care Using Povidone-iodine 1\% and Chlorhexidine $0.2 \%$ to the Amount of Bacteria on the Patients with Altered State of Consciousness}

\begin{abstract}
The oral care of unconscious patients should not be ignored and requires oral antiseptics that have antibacterial properties. This research was a quasi-experimental design with control groups, using pre-post test design. The study was aimed to compare the amount of bacteria colonies after oral care using povidone iodine $1 \%$ and chlorhexidine $0.2 \%$ on the patients with altered state of consciousness. Using consecutive sampling technique, 30 eligible respondents were divided into three groups. The results of this study identified that there was a significant decreased of the amount of bacteria colonies after oral care using povidone iodine $(p=0.007)$, chlorhexidine $(p=0.001)$ and water oral care $(\mathrm{p}=0.001)$. The difference of the number of colonies for oral care using povidone iodine $1 \%$, chlorhexidine $0.2 \%$, and the control group was not significant $(\mathrm{p}=0.343)$. It can be concluded that each of oral care using chlorhexidine $0.2 \%$, povidone iodine $1 \%$ and water has a significant ability to reduce colonies of bacteria and can be used as an oral care. For economic reason, it was advised to use water for oral care if clients do not experience oral infections, and to use chlorhexidine $0.2 \%$ or povidone iodine $1 \%$ when there is infection of the mouth.
\end{abstract}

Key words: Chlorhexidine $0.2 \%$, oral care, oral bacteria colonies, povidone iodine $1 \%$, unconsciousness. 
Ni Luh Widani : Perbandingan Oral Care Menggunakan Povidone Iodine 1\% dengan Chlorhexidine $0.2 \%$

\section{Pendahuluan}

Kesehatan mulut dapat dipengaruhi oleh beberapa faktor antara lain : faktor usia, kesehatan mental, pola makan kurang baik, immunosupresi, dehidrasi, pemberian oksigen, asupan oral tidak ada, dan obatobatan. Klien penurunan tingkat kesadaran mengalami kesulitan mempertahankan kondisi mulut yang sehat. Klien mengalami kesulitan menelan atau makan, sehingga sering menggunakan nasogastric tube (NGT). Klien cenderung mendapat terapi oksigen dan bernafas melalui mulut secara terus-menerus sehingga membran mucosa mulut menjadi kering. Kekeringan mulut dan asupan makanan yang tidak memadai, berdampak pada berkurangnya aliran saliva.

Saliva adalah cairan yang bersifat antibakteri dan bagian penting dari sistem pertahanan tubuh terhadap infeksi di mulut (Creven, 2009). Saliva mengandung zat antimikrobial spesifik (IgA) dan nonspesifik (lisozim, laktoferin, dan sialoperoksidase) membantu mengontrol microflora di mulut. Komponen kekebalan IgA (faktor imun adaptif) dan laktoferin (faktor imun bawaan) memberikan kontribusi untuk mengontrol pertumbuhan mikroorganisme dalam rongga mulut. Saliva berfungsi mengeluarkan plak secara mekanik dan mikroorganisme yang ada di dalam rongga mulut (Monro, 2008).

Rongga mulut merupakan pintu gerbang dari saluran pencernaan dan terdapat mikroorganisme terbanyak dari tubuh manusia. Lebih dari 500 jenis microorganism telah diisolasi dari mulut. Saliva mengandung banyak bakteri. Setiap milliliter saliva dijumpai 10 sampai 200 juta bakteri. Jumlah maksimum bakteri pada pagi hari atau setelah makan. Bakteri di rongga mulut antara lain: Streptococcus, Enterococcus, Diptheroid, Lactobaccili, Peptostreptococci, Actinomices, Veilonella, Bacteroides melaninogenicus, Fusuform dan Neisseria. Bakteri yang terdapat dalam plak antara lain: Leptotrichia, Actinomices, Streptococcus, dan Veillonela (Nobuhiro,2005). Bakteri di mulut yang sehat adalah flora normal yang tidak menimbulkan penyakit. Saat kondisi sakit, terutama klien penurunan tingkat kesadaran maka bakteri dari biofilm mulut dapat teraspirasi masuk ke saluran pernafasan yang dapat menimbulkan infeksi sistemik seperti pneumonia. Sopena dan Sabrina (2005) telah membuktikan etiology dari Hospital-Acquired Pneumonia (HAP) pada klien dewasa non ICU adalah jenis bakteri yang juga ditemukan di rongga mulut. Jenis bakteri terbanyak secara berurutan adalah $S$ pneumoniae, L pneumophila, Enterobacteria, Aspergillus sp, $P$ aeruginosa, Acinetobacter sp, $S$ aureu dan H influenzae.

Hospital-aquired pneumonia (HAP) yaitu pneumoni yang didapat di rumah sakit setelah 48 jam perawatan (CDC,2013). Insiden HAP sebanyak 15-20\% (Strausbaugh, 2000) dan menurut Edis (2009) insiden HAP terjadi 3,3/1000 klien. HAP berdampak pada peningkatan morbiditas, mortalitas, memperpanjang hari rawat (rata-rata 15,2 \pm 13,6 hari) dan meningkatkan biaya perawatan di rumah sakit, \$65.292 (Jean, 2008).

Pneumonia yang didapat di rumah sakit seharusnya tidak terjadi dan harus diupayakan pencegahannya. Pencegahan yang dapat dilakukan adalah dengan mencegah masuknya microorganisme di mulut ke saluran pernafasan melalui tindakan oral care secara tepat dan teratur. Prosedur oral care yang tepat meliputi pemilihan produk antiseptik dan teknik yang digunakan. Oral care pada klien dengan penurunan tingkat kesadaran tidak boleh diabaikan bahkan mereka membutuhkan oral care lebih sering dari pada klien sadar (Timby,2009). WHO telah merekomendasikan oral care sebagai langkah terbaik dalam mencegah Pneumonia dibandingkan penggunaan antibiotik (Plianbang, 2011 dalam Hillier ,2013).

Oral care untuk mengurangi atau mencegah pertumbuhan plak gigi yang mengandung bakteri dilakukan secara mekanis dengan menyikat gigi. Perawatan mulut hanya dengan menyikat gigi pada klien menurunkan kesadaran ternyata kurang efektif, maka dibutuhkan antiseptik yang mempunyai sifat antibakteri (Timby, 2009). Antiseptik yang bersifat antibakteri yang digunakan dalam oral care klien di rumah sakit bervariasi, diantaranya petroleum jelly, sodium chloride $(\mathrm{NaCl})$, povidone iodine dan chlorhexidine.

Berdasarkan pengamatan peneliti dan hasil wawancara dengan beberapa perawat di Pelayanan Kesehatan (PK) Sint Carolus 
Ni Luh Widani : Perbandingan Oral Care Menggunakan Povidone Iodine 1\% dengan Chlorhexidine 0.2\%

didapatkan antiseptik yang digunakan adalah povidone iodine $1 \%$ bila klien mengalami infeksi di mulut dan menggunakan air putih/air minum atau tidak menggunakan antiseptik bila tidak ada tanda infeksi. Antiseptik chlorhexidine belum pernah digunakan dalam perawatan mulut. Keluhan yang diungkapkan oleh perawat sehubungan dengan penggunaan povidone iodine adalah baunya yang tidak segar dan terasa lengket atau tidak bersih, jadi walaupun klien sudah menggunakan antiseptik povidone-iodine $1 \%$ mulut klien masih bau dan kotor.

Antiseptik dalam bentuk obat kumur mempunyai peran ganda yaitu pencegahan langsung pertumbuhan plak dan sebagai terapi langsung terhadap plak gigi. Antiseptik pembersih mulut yang efektif adalah yang tidak mengandung alkohol. Alkohol dalam kandungan antiseptik akan menimbulkan rasa perih dan bahkan memicu pertumbuhan microorganisme. Antiseptik yang direkomendasikan oleh persatuan dokter gigi (BDA, 2009) adalah chlorhexidine. Alasannya, chlorhexidine sebagai antibakteri spektrum luas dan sebagai antijamur dapat mencegah dan mengobati terbentuknya plak gigi dan chlorhexidine sebagai anti karies (Hillier, 2013).

Beberapa peneliti telah membuktikan efektifitas antiseptik pada oral care. Antiseptik yang sering digunakan adalah povidone iodine dan chorhexidine. Seguin (2006) meneliti 98 klien trauma kepala dengan Glasgow Coma Score $\leq 8$ dan ventilator $\geq 2$ hari. Sample dibagi dalam 3 kelompok yaitu povidone iodine $\mathrm{n}=36$, saline group $\mathrm{n}=31$ dan kelompok kontrol $n=31$, menyimpulkan bahwa povidone iodine sebagai strategi yang efektif untuk menurunkan prevalensi ventilator-associated pneumonia (VAP) pada klien tauma kepala berat. Penelitian yang dilakukan oleh Kumari (2013) terhadap 60 pasien dengan defisit perawatan diri di India, menyimpulkan bahwa penggunaan Chorhexidine $0.2 \%$ lebih efektif dari pada prosedur rutin dalam meningkatkan status kesehatan mulut dan menurunkan jumlah coloni microorganisme di mulut pasien dengan defisit perawatan diri. Hasil penelitian menunjukkan ada perbedaan yang signifikan status kesehatan mulut antara pasien yang mendapat obat kumur chorhexidine $0.2 \%$ dengan kontrol $(\mathrm{p}=0.001)$.

Penelitian menggunakan antiseptik povidone iodine ataupun chorhexidine masing-masing terbukti efektif dalam pencegahan pneumonia. Perawat harus memiliki kemampuan dalam memilih produk antiseptik yang tepat dan bermanfaat bagi klien. Produk antiseptik yang dipilih dalam prosedur oral care perlu pembuktian. Peneliti ini ingin membuktikan antiseptik yang lebih berpengaruh dalam mengurangi jumlah kuman di mulut dengan tindakan keperawatan oral care dengan membandingkan antiseptik chlorhexidine $0.2 \%$ dan povidone-iodine $1 \%$. Dosis chlorhexidine $0.2 \%$ yang ditetapkan berdasarkan penelitian Mangundjaja (2000) terhadap 10 responden yang tidak sakit dan menyatakan bahwa chlorhexidine $0.2 \%$ efektif membunuh kuman Streptococcus mutan di dalam air liur. Melalui penelitian ini pula diharapkan perawat menyadari perannya dalam menjaga kebersihan dan kesehatan mulut sehingga klien terhindar dari nosokomial infeksi khususnya pneumoni yang merupakan bagian dari bentuk caring terhadap klien tidak sadar (Joe, 2008). Penelitian ini bertujuan untuk mengidentifikasi perbedaan pengaruh tindakan keperawatan oral care povidone-iodine $1 \%$ di bandingkan dengan chlorhexidine $0.2 \%$ dan kontrol menggunakan air minum terhadap jumlah bakteri di mulut klien dengan penurunan kesadaran.

\section{Metode Penelitian}

Penelitian ini merupakan penelitian kuantitatif, menggunakan desain penelitian eksperimen semu (quasi experiment) pre dan post test design dengan kelompok kontrol (group control) sebanyak 30 responden.

Rancangan penelitian ini untuk menguji pengaruh tindakan keperawatan oral care antara chlorhexidine $0.2 \%$ dibandingkan dengan povidone-iodine $1 \%$ dan dengan air minum sebagai kelompok kontrol, terhadap jumlah bakteri di mulut. Pengukuran jumlah bakteri dilakukan dengan cara pemeriksaan swab mulut sebelum intervensi oral care dengan povidone iodine $1 \%$, chlorhexidine $0.2 \%$ dan air minum diberikan, kemudian pengukuran yang sama dilakukan satu jam setelah intervensi. Sampel pemeriksaan 
Ni Luh Widani : Perbandingan Oral Care Menggunakan Povidone Iodine 1\% dengan Chlorhexidine $0.2 \%$

dimasukkan ke dalam media transport (lactose broth) dan segera dikirim ke laboratorium Pelayanan Kesehatan Sint Carolus dan selanjutkannya dibiakkan dengan media agar selama 48 jam pada suhu $37,5^{\circ} \mathrm{C}$, setelah itu dihitung jumlah koloni bakteri yang tumbuh.

Kriteria inklusi sampel penelitian ini adalah klien yang dirawat di unit medikal bedah dewasa dengan kesadaran kualitatif apatis sampai dengan koma, tingkat kesadaran kuantitatif GCS $\leq 12$, mendapat terapi O2, menggunakan NGT, berusia lebih dari 18 tahun serta klien dan keluarga bersedia menjadi responden. Kriteria eksklusinya adalah klien mempunyai riwayat alergi terhadap povidone-iodine atau chlorhexidine, adanya riwayat penyakit tiroid pada kelompok menggunakan povidone-iodine dan adanya gangguan imunitas seperti : HIV-AIDS, dan leukemia.

\section{Hasil Penelitian}

Distribusi responden berdasarkan jumlah koloni bakteri di mulut terdiri dari jumlah koloni bakteri sebelum oral care dan selisih

Tabel 1 Distribusi Jumlah Koloni Bakteri di Mulut Sebelum Oral Care Menurut Kelompok di PK Sint Carolus ( $\mathbf{N = 3 0 )}(\mathbf{0 0 0})$

\begin{tabular}{cccrrc}
\hline \multicolumn{1}{c}{ Variabel } & $\mathbf{n}$ & Mean & Median & SD & \multicolumn{1}{c}{ Min - Mak } \\
\hline Povidone iodine 1\% & 10 & 5210 & 3500 & 4253 & $400-10000$ \\
Chlorhexidine 0.2\% & 10 & 6490 & 8000 & 3980 & $600-10000$ \\
Air minum & 10 & 4490 & 4600 & 2835 & $800-92000$ \\
\hline
\end{tabular}

Tabel 2 Distribusi Selisih Jumlah Koloni Bakteri di Mulut Sebelum dan Setelah Oral Care Menurut Kelompok di PK Sint Carolus ( $n=30)$ dalam (000)

\begin{tabular}{lccccc}
\hline \multicolumn{1}{c}{ Variabel } & $\mathbf{n}$ & Mean & Median & SD & Min - Mak \\
\hline Povidone iodine 1\% & 10 & 5210 & 2850 & 3927 & $100-9500$ \\
Chlorhexidine 0.2\% & 10 & 6490 & 6670 & 3974 & $540-9930$ \\
Air minum & 10 & 4490 & 3810 & 1092 & $200-6300$ \\
\hline
\end{tabular}

Tabel 3 Hasil Analisis Perbandingan Selisih Jumlah Koloni Bakteri di Mulut pada Kelompok Intervensi dan Kelompok Kontrol (000)

\begin{tabular}{lccccc}
\hline \multicolumn{1}{c}{ Variabel } & Mean & SD & SE & P Value & \% \\
\hline Jumlah Koloni bakteri & & & & & \\
Sebelum Oral Care & 5210 & 4253 & 1344 & 0,007 & 82 \\
Setelah Oral Care & 929 & 1156 & 365 & & \\
Selisih & 4281 & 3927 & 1241 & & \\
\hline
\end{tabular}

Tabel 4 Hasil Analisis Perbedaan Jumlah Koloni bakteri Mulut Sebelum dan Setelah Oral Care pada Kelompok Chlorhexidine 0.2\% di PK Sint Carolus ( $\mathrm{N}=10)$ dalam (000)

\begin{tabular}{lrrrrc}
\hline \multicolumn{1}{c}{ Variabel } & Mean & SD & SE & P Value & \% \\
\hline Jumlah Koloni bakteri & & & & & \\
Sebelum Oral Care & 6490 & 3980 & 1258 & 0,001 & 89 \\
Setelah Oral Care & 706 & 713 & 225 & & \\
Selisih & 5784 & 3974 & 1256 & & \\
\hline
\end{tabular}


Ni Luh Widani : Perbandingan Oral Care Menggunakan Povidone Iodine 1\% dengan Chlorhexidine $0.2 \%$

$\begin{aligned} & \text { Tabel } 5 \text { Hasil Analisis } \\
& \text { Povidone Iodine 1\% dengan Chlorhexidine 0.2\% di PK Sint Carolus } \\
& \text { (n=30) dalam (000) }\end{aligned}$
\begin{tabular}{ccccc} 
Variabel & N & Mean & SD & P Value \\
\hline Povidone iodine 1\% & 10 & 812 & 1201 & \multirow{2}{*}{0,38} \\
Chlorhexidine $0.2 \%$ & 10 & 1536 & 2289 & \\
\hline
\end{tabular}

jumlah koloni bakteri sebelum dan setelah oral care. Tabel 1 dan 2 mendeskripsikan jumlah koloni bakteri di mulut.

Tabel 1 menjelaskan bahwa distribusi jumlah koloni bakteri sebelum oral care paling banyak ditemukan pada kelompok Chlorhexidine $0.2 \%$ yaitu dengan rata-rata 6.490.000 dengan standar deviasi 4.253.000, dengan jumlah terrendah 600.000 dan tertinggi 10.000.000. Jumlah koloni bakteri paling sedikit pada kelompok air minum yaitu rata-rata 4.490 .000 dengan standar deviasi 2.385.000, dengan jumlah terendah 800.000 dan tertinggi 9.000.000.

Distribusi rata-rata selisih jumlah koloni bakteri sebelum dengan sesudah oral care paling tinggi pada kelompok Chlorhexidine $0.2 \%$ yaitu 5.784.000 dengan standar deviasi 6.670.000. Selisih rata-rata jumlah koloni bakteri terendah pada kelompok air minum yaitu 3496.000 .

Uji statistik yang digunakan untuk membandingkan jumlah koloni bakteri di mulut sebelum intervensi dan setelah intervensi dilakukan dengan Uji t dependen. Perbandingan jumlah koloni bakteri sebelum dan setelah intervensi dengan menggunakan povidone iodine $1 \%$ dan chlorhexidine $0.2 \%$ dapat terlihat pada tabel 3 dan tabel 4 .

Hasil analisis didapatkan rata-rata jumlah koloni bakteri mulut sebelum oral care adalah 5.210.000 dan setelah oral care menggunakan povidone iodine $1 \%$ adalah 929.000. Nilai rata-rata perbedaan jumlah koloni bakteri sebelum dan setelah oral care adalah 4.281.000. Hasil uji statistik didapatkan nilai $\mathrm{p}=0,007$, maka dapat disimpulkan ada perbedaan yang signifikan jumlah koloni bakteri mulut sebelum dan setelah oral care pada kelompok povidone iodine $1 \% \quad(p=0,007, \alpha=0,05)$, dengan penurunan jumlah koloni bakteri sebanyak 82\% (Tabel 3).

Tabel 4 terlihat hasil analisis didapatkan rata-rata jumlah koloni bakteri mulut sebelum oral care adalah 6.490.000, sedangkan setelah intervensi oral care menggunakan chlorhexidine $0.2 \%$ adalah 706.000 . Nilai rata-rata perbedaan jumlah koloni bakteri sebelum dan setelah oral care adalah 5.784.000. Hasil uji statistik didapatkan nilai $\mathrm{p}=0,001$, maka dapat disimpulkan ada perbedaan yang signifikan jumlah koloni bakteri mulut sebelum dan setelah oral care pada kelompok Chlorhexidine $0.2 \%$ $(p=0,001, \alpha=0,05)$ dengan penurunan jumlah koloni bakteri sebanyak $89 \%$.

Perbedaan Jumlah Koloni Bakteri antara Kelompok Povidone Iodine $1 \%$ dengan Chlorhexidine $0.2 \%$ dilakukan dengan Uji T Independen, dilihat pada tabel 5.

Hasil analisis didapatkan rata-rata jumlah koloni bakteri di mulut post intervensi paling banyak pada kelompok chlorhexidine $0.2 \%$ yaitu dengan rata-rata 1.536 .000 dan hasil uji statistik didapatkan nilai $\mathrm{p}=0,38$, maka dapat disimpulkan secara statistik tidak ada perbedaan yang signifikan rata-rata jumlah bakteri diantara antara kelompok povidone iodine $1 \%$ dan chlorhexidine $0.2 \%$.( Tabel 5 ).

\section{Pembahasan}

Pengaruh oral care menggunakan povidone iodine $1 \%$ terhadap penurunan jumlah koloni bakteri mulut, hasil penelitian terhadap 10 responden yang menggunakan povidone iodine $1 \%$ untuk oral care $(n=30)$ ditemukan bahwa rata-rata jumlah koloni bakteri sebelum (5.210.000) dan setelah oral care (929.000) dengan selisih penurunan rata-rata koloni bakteri sebanyak 4.281.000 dengan nilai $\mathrm{p}=0,007$. Jadi secara statistik menunjukkan bahwa penggunaan povidone iodine $1 \%$ secara signifikan mampu menurunkan koloni bakteri yang ada di mulut.

Povidone iodine $1 \%$ sebagai antiseptik 
Ni Luh Widani : Perbandingan Oral Care Menggunakan Povidone Iodine 1\% dengan Chlorhexidine $0.2 \%$

rongga mulut, bersifat microbisidal terhadap sebagian besar bakteri, jamur, protozoa, virus dan jamur. Povidone iodine 1\% mudah larut dalam air dingin, etil alkohol, isopropil alkohol, glikol polietilen, dan gliserol. Free yodium, perlahan-lahan dibebaskan dari yodium-poviodine (PVP-I) kompleks dalam larutan, membunuh sel-sel eukariotik melalui iodinasi lipid dan oksidasi senyawa sitoplasma dan membran. Agen ini menunjukkan berbagai kegiatan microbicidal terhadap bakteri, jamur, protozoa, dan virus. Rilis yang lambat yodium dari kompleks PVPI dalam larutan yodium meminimalkan toksisitas terhadap sel mamalia. Pada dasarnya, povidone-iodine merupakan iodine kompleks yang berfungsi sebagai antiseptik yang mampu membunuh mikroorganisme seperti bakteri, jamur, virus, protozoa, dan spora bakteri (Bethadine,2007).

Nagatake, (2002) membuktikan efektifitas povidone iodine dalam menurunkan kejadian infeksi pernafasan kronis secara signifikan. Demikian juga Seguin (2006) telah membuktikan efektifitas povidone iodine dalam mencegah terjadinya pneumoni akibat penggunaan ventilator dan Satomura (2005) telah membuktikan efektifitas dari povidone iodine sebagai antiseptik oral dalam mencegah terjadinya infeksi saluran pernafasan atas. Tetapi study meta-analysis oleh Li Longti, et.al (2015) terhadap 17 RCT, 4249 sample membuktikan povidone iodine tidak efektif dalam menurunkan kejadian Ventilator Associated Pneumonia $(\mathrm{P}=0.438$; $>0.05$ ).

Pengaruh oral care menggunakan chlorhexidine $0.2 \%$ terhadap penurunan jumlah koloni bakteri mulut, hasil penelitian terhadap 10 responden yang menggunakan chlorhexidine $0.2 \%$ untuk oral care $(n=30)$ ditemukan bahwa rata-rata jumlah koloni bakteri sebelum oral care (6.490.000) dan setelah oral care (706.000) dengan selisih penurunan rata-rata koloni bakteri sebanyak 5.784.000 dengan nilai $p=0,001$. Jadi secara statistik menunjukkan bahwa penggunaan chlorhexidine $0.2 \%$ secara signifikan mampu menurunkan koloni bakteri yang ada di mulut. Mendukung penelitian ini adalah studi yang dilakukan oleh Meckel, A. H. (2009) yang perbandingan efektifitas obat kumur chlorhexidine normal saline dan sanguinarine terhadap plak gigi dan radang gusi, didapatkan bahwa berkumur dengan $0,2 \%$ Chlorhexidine secara signifikan mengurangi gingivitis ( sebanyak 31\%), perdarahan gingiva (sebanyak 39\%), dan plak (sebanyak 49\%) dan secara signifikan chorhexidine $0.2 \%$ lebih baik daripada Normal saline dan Sanguinarine sebagai oral care ( $\mathrm{P}$ $<0,05)$. Hasil penelitian menunjukkan secara signifikan chlorhexidine mengurangi semua mikroba mulut sedangkan perawatan dengan salin normal efektif dalam mengurangi hanya 3 dari 5 mikroba.

Demikian juga study metaanalisa oleh Li Longti, et.al (2015) terhadap 17 RCT, 4249 sample membuktikan chlorhexidine efektif dalam menurunkan kejadian Ventilator Associated Pneumonia ( $\mathrm{P}=0.012 ;>0.05)$. Chlorhexidine sebuah bis-biguanide kationik biocide dengan toksisitas rendah terhadap mamalia dan aktivitas antibakteri spektrum luas, menyebabkan terhambatnya pertumbuhan dan kematian sel bakteri (McBain, 2003). Chlorhexidine, sampai saat ini adalah agen anti plak yang paling ampuh. Chlorhexidine dianggap sebagai gold standar agen anti plak. Sifat antimikroba dari Chlorhexidine dikaitkan dengan molekul bi-kationik (Mathur,2011).

Perbandingan oral care menggunakan Povidone Iodine $1 \%$ dengan Chlorhexidine $0.2 \%$ terhadap jumlah koloni bakteri di mulut, hasil penelitian ini menunjukkan perbedaan penurunan jumlah koloni bakteri mulut oral care menggunakan povidone iodine $1 \%$ dengan chlorhexidine $0.2 \%$ $\mathrm{p}=0,38$. Jadi secara statistik pada alpha 0.05 chlorhexidine $0.2 \%$ tidak lebih baik dari pada povidone iodine $1 \%$ atau sebaliknya povidone iodine $1 \%$ tidak lebih baik dari pada chorhexidine $0.2 \%$ dalam menurunkan jumlah koloni bakteri di mulut pada klien dengan penurunan tingkat kesadaran.

Hasil uji ini menunjukkan bahwa diantara povidone iodine $1 \%$ dan chlorhexidine $0.2 \%$ sama-sama memiliki pengaruh yang signifikan dalam menurunkan koloni bakteri di mulut, namun dari perbedaan selisih penurunan koloni bakteri menunjukkan chlorhexidine $0.2 \%$ mampu menurunkan $89 \%$ dan povidone iodine $82 \%$ jumlah koloni bakteri di mulut atau chlorhexidine $0.2 \%$ memiliki kemampuan paling banyak 
Ni Luh Widani : Perbandingan Oral Care Menggunakan Povidone Iodine 1\% dengan Chlorhexidine $0.2 \%$

dalam menurunkan jumlah bakteri di mulut.

Hasil penelitian ini berbeda dengan penelitian Neeraja (2008). Penelitian terhadap 45 responden usia 6-12 tahun dibagi menjadi tiga kelompok yaitu dengan berkumur menggunakan povidone iodine $1 \%$, chlorhexidine $0.2 \%$ dan placebo dua kali sehari selama 14 hari. Disimpulkan bahwa berkumur dapat dilakukan dalam menurunkan jumlah S. mutans dalam hal ini berkumur harus menggunakan chlorhexidine dan dapat direkomendasikan karena telah terbukti memiliki pengaruh yang lebih baik dari povidone-iodine dan plasebo.

\section{Simpulan}

Penggunaan antiseptik (chlorhexidine 0.2\% dan povidone iodine 1\%) dan non-antiseptik (air minum) secara statistik telah terbukti secara signifikan dapat menurunkan jumlah rata-ratakolonibakteri dimulut.Perbandingan efektifitas ketiga cairan tersebut terhadap penurunan rata-rata jumlah koloni bakteri di mulut terbukti secara statistik tidak ada yang signifikan lebih baik. Ketiga cairan tersebut dapat digunakan sebagai cairan pembilas pada saat oral care. Hasil penelitian ini juga menyimpulkan dari ketiga cairan tersebut secara deskriptif chlorhexidine $0.2 \%$ lebih mampu menurunkan jumlah koloni bakteri dari pada povidone iodine $1 \%$.

Hasil penelitian ini menyimpulkan ketiga cairan pembilas oral care dapat digunakan pada klien untuk mencegah pertumbuhan dan perkembangan microorganisme di mulut. Penelitian ini hanya melihat penurunan rata-rata jumlah bakteri di mulut sebelum dengan sesudah oral care, belum melihat dampak lanjut terhadap pencegahan terjadinya pneumonia. Diharapkan dengan berkurangnya jumlah koloni bakteri di mulut maka risiko teraspirasi microorganisme ke saluran pernafasan dapat dicegah sehingga dapat meminimalkan terjadinya pneumonia.

Beberapa studi yang telah dilakukan, produk yang banyak dipilih untuk perawatan mulut adalah chlorhexidine terutama chlorhexidine $0,2 \%$. Namun, bebarapa peneliti merekomendasikan untuk meneliti kembali pengaruh konsentrasi/kepekatan dari chlorhexidine. Tiga studi yang menggunakan chlorhexidine $0,2 \%$ menunjukkan hasil yang kurangefektifdalammencegahpneumoniadan dua studi yang menggunakan chlorhexidine $2 \%$ menunjukkan chlorhexidine $2 \%$ aman dan efektif untuk mencegah VAP. Jadi belum ada penelitian yang secara empiris menentukan kepekatan/konsentrasi yang baik dan produk untuk perawatan mulut. Penelitian selanjutnya harus menganalisa konsentrasi terbaik dari chlorhexidine untuk perawatan mulut, teknik mengaplikasikannya dan frekuensi dilakukannya perawatan mulut sebagai pencegahan terbaik munculnya pneumonia (Hillier,2013).

\section{Daftar Pustaka}

Bethadine. (2007) http:www. Bethadine -ina. com diakses tanggal 6 Februari 2010

British Dental Association (2009). www.bda. org.

Edis, C .et.al (2009) Hospital-acquired pneumonia developed in non-intensive care units. Respiration., 78(4):416-22. doi: 10.1159/000232392. Epub 2009 Jul 31

Hillier. B, Wilson. C ,Chamberlain, King Lindy (2013) Preventing VentilatorAssociated Pneumonia Through Oral Care, Product Selection, and Application Method. A Literatur Review. Advanced Critical Care, 24(1). Pp 38-58.

Jean C.et.al (2008) Prevention of Hospital-Associated Pneumonia Using a Comprehensive Oral Hygiene Protocol. http://www. Segeproducts.com

Joe. V. (2008) Caring for Unconscious patient. http://allnurses.com.

Kumari, N. (2013). Effectiveness of $0.2 \%$ chlorhexidine and oral routine care in terms of oral health status and oral microbiological colony count of self care deficit clients, Experimental study. Journal of Dental and Medical Sciences, 11(5), 1-6. http://dx.doi. org/10.9790/0853-1150106.

Li Longti, A et. Al (2015) Can Routine Oral 
Ni Luh Widani : Perbandingan Oral Care Menggunakan Povidone Iodine 1\% dengan Chlorhexidine $0.2 \%$

Care With Antiseptics Prevent VentilatorAssociated Pneumonia in Patients Reveiving Mechanical Ventilation? An update Metaanalysis from 17 Randomized Controlled Trials. Int J Clin Exp Med;8(2):1645-1657. www.ijcem.com.

Mangundjaja, S (2000) Pengaruh Obat Kumur Chlorhexidine terhadap Populasi Kuman Streptococcus mutan di dalam Air Liur. Bagian Biologi Mulut FKG UI.

Mathur S, mathur $\mathrm{T}$, shrivastava $\mathrm{R}$, khatri R. (2011) Chlorhexidine:The gold standard in chemical plaque control. Natl J Physiol Pharm Pharmacol, 1(2): 45-50.(review article)

McBain A, Bartolo R, Catrenich C, Charbonneau D, Ledder R, Gilbert P. (2003) Effects of a chlorhexidine gluconatecontaining mouth wash on the vitality and antimicrobial susceptibility of in vitro oral bacterial ecosystems applied and environmental. Microbial J;69:4770-6.

Meckel. A.H., (2009) The LongTerm Effect of a Mouthrinse with $0.2 \%$ chlorhexidine on Dental Plaque and Gingivitis: A Systematic Review" J ClinPeriodontol, 78(7), 12181228.

Monro C.L, Grap M.J, Jablonski R., Boyle Anne ( 2008) Oral Health Measurement in Nursing Research: State of the Science. Biol Res Nurs, 8(1).

Nagatake, Ahmed, Oishi (2002) Prevention of Respiratory Infection by Povidone-Iodine Gargle. Dermatology,204:32-36

Neeraja (2008) The effect of povidone-iodine and chlorhexidine mouth rinses on plaque
Streptococcus mutans count in 6- to 12-yearold school children: An in vivo study.

Nobuhiro Takahashi (2005) Microbial ecosystem in the oral cavity: Metabolic diversity in an ecological niche and its relationship with oral diseases. International Congress Series 1284:103-112. www.ICS. elsevier.com.

Satomura et. al (2005) Prevention of Upper Respiratory Tract Infections by Gargling: A Randomized Trial.

Seguin (2006) Effect of oropharyngeal decontamination by povidone-iodine on ventilator-associated pneumonia in patients with head trauma. Neurologic Critical Care 34(5) : 1514-1519 May 2006.

Setiawan, Reniart, Oewen (2005) Comparisson Effects of Chlorhexidine Gluconate and Povidone Iodine Mouth Washes to Chemotherapy-Induced Oral Mucositis in Children With Acute Lymphoblastic Leukemia.

Sopena dan Sabria ( 2005) Multicenter Study of Hospital-Acquired Pneumonia in NonICU Patients. CHEST 2005; 127:213-219.

Strausbaugh, L.J. (2000) Nosocomial respiratory infections. in: G.L. Mandel, J.E. Bennett, R. Dolin (Eds.) Mandell, Douglas, and Bennett's Principles and Practice of Infectious Diseases. 5th ed. Churchill Livingstone, Philadelphia, Pa; 2000:30203028 .

Timby K.(2009) Fundamental of Nursing Skill and Conceps. Edition 9 th. Lippincott. Wllians \& Wilrins. P: 366. 